\title{
Origins of Public Health Nursing in Israel
}

\author{
Rebecca Adams, R.N., D. Ed.
}

Chairman, Department of Nursing, Tel-Aviv University

\section{OPSOMMING}

Israel is nou dertig jaar oud, maar sy gemeenskapsgesondheidsdienste dateer van die begin van die eeu toe die land nog onder Turkse heerskappy was. Die eerste geskrewe verslae oor verpleegdienste in Israel het in 1912 in New York-stad in the notule van 'n groep Joodse vroue (later die Hadassah-vroueorganisasie) verskyn. Sommige van die lede het die Heilige Land besoek en was so geskok deur die gesondheidstoestand van die armes onder die Jode dat húlle verbeterde sorg as dringend noodsaaklik beskou het.

Die Hadassah-vroue het twee verpleegsters na Jerusalem gestuur. Meji. Rachel Landy and Rose Kaplan het, vergesel van die Amerikaanse filantroop, Mnr Nathan Straus ${ }^{2}$ en sy eggenote, in Januarie 1913 daar aangekom.

Tot in 1918 was daar so goed as geen staatsgesondheidsdienste nie. Hospitale en ander maatskaplike inrigtings soos weeshuise en tehuise vir bejaardes is deur godsdienstige en vreemde volksgroepe van Jode en Christene beheer. Die meeste inrigtings vir gesondheidsorg was in Jerusalem gekonsentreer en kon nie in die behoeftes van die hele Joodse bevolking voorsien nie.

Sanitêre toestande wat vir die gesondheidstoestand van 'n bevolking belangrik is, was betreurenswaardig en openbare sanitasie was so te sê onbekend.

Die toestand was egter nie so totaal somber nie, want daar is sekere gemeenskapsgesondheidsdienste deur vrywillige Joodse groepe ingestel. Die Joodse Gesondheidsburo wat in 1912 gestig en geldelik deur Nathan Straus gedra is, het met die uitwissing van malaria en tragoom begin. Die Pasteur-instituut in Jerusalem wat in 1913 deur Joodse dokters gestig is, was die enigste produsent van entstof teen pokke en hondsdolheid totdat die Britte op die toneel verskyn het. 20

Die verpleegsters moes aanvaar word in 'n gemeenskap waar vroue, onder die Arabiere so wel as die Ortodokse Jode, 'n baie lae posisie beklee het. ${ }^{22}$ Bowendien het hulle met liggaamlike ontbering te kampe gehad.

Teen Junie 1915 is albei verpleegsters teruggeroep en met hulle vertrek is die ontwikkeling van gemeenskapsverpleging by wyse van 'n distriksverpleegprogram onderbreek, omdat daar geen opgeleide verpleegsters was om die program oor te neem nie. Die sukses wat mejj. Landy en Kaplan behaal het, het egter die grondslag gelê vir gemeenskapsverpleging waarmee ander verpleegsters weer in 1922 begin het. 
TRAEL is now thirty years old, but its community health services date back to the early years of this century when the land was still under Turkish rule. The first written reports on the nursing services appeared in 1912 in New York City in the minutes of a group of Jewish women later known as Hadassah Women's Organization. Some of the members had visited the Holy Land and, shocked by the state of health of the Jewish poor, saw the urgent need for improving care. It was decided to start with a system of community maternity nursing which would be carried out along the lines of the New York State Legislation. The nurses would be given funds to employ midwives, to supply linen to mothers and babies, and to distribute money for medicine and food to the poor. Furthermore, the nurses were to train probationers for community nursing, give talks to mothers and girls and nursing care to the sick poor. They were to be in contact with Hadassah by letters, monthly reports, and were to use an approved system of bookkeeping 1 .

With the example of Lillian Wald's Henry Street Settlement nursing program and its philosophy of care for the poor in mind, the Hadassah women sent two nurses to Jerusalem. The Misses Rachel Landy and Rose Kaplan arrived in January 1913 accompanied by the American philanthropist Mr. Nathan Straus ${ }^{2}$ and his wife. What they saw, heard and learned of the area makes fascinating reading for nurse and non-nurse alike.

The Canaan of Genesis XVII:8 was Palestine to Greeks, Romans, Christians and Arabs. In 1516 it became part of the Turkish empire and was known as the southern part of the vilayet or province of Syria ${ }^{3}$. To the Jews, Palestine had a special significance not shared with earlier or later rulers; it was Eretz Israel - the land promised to their forefathers:

Lift up thine eyes and look from the place where thou art northward, southward, eastward and westward; for all the land thou seest, to thee will I give it, and to thy seed forever ${ }^{4}$.

Of the peoples who had crossed and inhabited the area, some disappeared from history, but Jews, descendants of the Babylonian exiles, stayed in the country into modern times. Beside these, there were communities set up by Jews who had been expelled from Spain in the fifteenth century and settled in the holy cities of Jerusalem and Safad ${ }^{5}$. These Jews and some co-religionists from Eastern Europe lived in closed, poverty-stricken communities, filled with illness and neglect, and waited for the Messiah ${ }^{6}$.

\section{Zionism}

The latter half of the nineteenth century saw the emergence in Europe of a nationalist movement, called Zionism, which had as its aim the return of Jews to Palestine, and the establishment of a Jewish state there. As a result of this awakening, the first wave of organized immigration ${ }^{7}$ came into the country between 1882 and 1903 from Russia and Roumania, spearheaded by a group that called itself the "Bilu" 8 . It was in these years that the New Yishuv began to form; twentyfive thousand Jews from those countries came to Palestine after the pogroms of 1881 to find freedom. Although the Turks forbade Jews to settle in Palestine, the latter managed, by bribery and by virtue of their Russian passports, to remain. With the help of the French philanthropist Baron Edmond de Rothschild, twelve villages were established. including Zikhron Yaacov, Rishon le Tzion, and Rosh Pina. Thus the capitalist house of Rothschild and the socialist dreamers from Eastern Europe cooperated in rebuilding the country.

In the late nineteenth century Zionism, as a politica movement, came into being. Its origin is usually dated from the appearance of a seminal book, The Jewish State, written by Theodor Herzl, a journalist sent to report on the Dreyfus trial in Paris in 1894. The violent anti-semitism then manifesting itself in supposedly liberal France shocked him. The book and the man fired the imagination of many young Jews in the late nineteenth and early twentieth centuries ${ }^{9}$, and inspired new waves of Jewish immigration to Palestine.

The second Aliyah, between 1904 and 1913, numbered some 40000 persons from Eastern Europe, among them many of the future leaders of Israel. David Ben Gurion, Levy Eshkol, and Itzhak Ben Zvi; others were to become the founders of the labour unions and political parties. While nationalism, socialism, and manual labour were the ideals, more then half of these immigrants left for the United States or returned to Europe because of the hard work in agriculture, for which they had little experience, and because of illness and economic difficulties ${ }^{10}$

At the same time that immigrants from Europe with their various political leanings sought dignity and independence in Palestine, Jewish groups from the surrounding Arab countries also came, seeking a haven ${ }^{11}$. The Oriental Jews numbered about 20000 before the First World War, and some 70000 came after 1918. According to Eisenstadt, the European Jews for the most part negated traditional religious culture in the modern society they wanted to build: the Oriental Jews, among them pedlars, unskilled labourers, and some wealthy traders, wanted to remain as large patriarchal families with religion and tradition as the way of life ${ }^{12}$

Thus, the Jewish population, estimated at about 85 90000 out of a total of 650000 inhabitants between 1912 and $1917^{13}$, was made up of the Middle Eastern Jews in closed communities with Messianic hopes, some religious Jews from Eastern Europe, and new groups of European Jews with ideas frequently diametrically opposed to those of the others ${ }^{14}$.

\section{Conditions in Palestine}

To the Jews coming from more advanced countries, conditions in Palestine must have been a shock. Transportation and communication were most primitive. The Turks had done 
almost nothing, except the building of some main roads; secondary and local roads were few and poor, the means of transportation being some horse-drawn vehicles and, mainly, camels, mules and donkeys. In 1914 there was one motor car in Palestine and two narrow-gauge railway lines connected Jaffa with Jerusalem, and Haifa with Damascus. Telegraph and telephone services were nonexistent, and postal services were conducted under the aegis of several European powers. The currency of the country was Egyptian, but Turkish gold coins and a few Maria Theresia thalers were also used in commerce ${ }^{15}$.

Almost no government health services existed until 1918 . Although the Turks had a plan for a medical service, it was never implemented, except for the employment of municipal doctors at very low salaries ${ }^{16}$ - Hospitals and other social institutions, such as orphanages and old persons' homes, were run by religious and foreign national groups of Jews and Christians. Most health care institutions were concentrated in Jerusalem and could not meet the needs of the entire Jewish population. Moreover, Jews, wary of Christian missionary activities, would use only Jewish facilities, thus overloading them ${ }^{17}$.

Official preventive care facilities were nonexistent, and, judging by later reports of the British, typhus, relapsing fever, typhoid, and paratyphoid were endemic, at times epidemic, and nearly everyone suffered from trachoma ${ }^{18}$. It must be noted that under the Turks there was no reporting of vital statistics or disease, so that quantitative statements are at best of limited value.

Sanitary conditions, important for the state of health of a population, were deplorable, and public sanitation was almost unknown. Besides the heaps of refuse on which, in antiquity, generation after generation had built their communities, similar heaps were accumulated by people living in the first decades of the twentieth century. Flies were considered a nuisance at most, but never a source of disease. Water supplies came from uncovered wells and cisterns, breeding places for mosquitoes, and unprotected from dust and foreign bodies ${ }^{19}$.

The situation was not totally dismal, for some public health services were instituted by voluntary Jewish groups. The Jewish Health Bureau, founded in 1912 and supported financially by Nathan Straus, began malaria and trachoma eradication; the Pasteur Institute in Jerusalem, founded in 1913 by Jewish physicians, was the sole producer of smallpox and anti-rabies vaccine until the British came ${ }^{20}$

The Jewish population the nurses saw was poor and hungry; the homes often had no bedding, no water, no heating. The saving grace was that these hovels were on the ground floor, and for most of the year one could easily be out of doors. Superstition regarding health practices was rife, and treatment by the wise man often more acceptable than that of the physician. Nursing care in the home was given by the women in the family, according to the prescription of the native practitioner and to the lore which had been passed on from generation to generation ${ }^{21}$.

The nurses had to be accepted in a community where women had very low status among Arabs as well as among the Orthodox Jews ${ }^{22}$. In addition, they had to cope with physical hardships. Water had to be carried from the pump into the settlement which was part clinic and part home. Heating and cooking were done on the evil-smelling kerosene stove or on a dangerous contraption which was as likely as not to explode if not treated with circumspection.

\section{The Nursing Programme 1913 - 1915}

The nurses considered health education, social work, cooperation with physicians and community agencies an integral part of their care program. A report sent to Hadassah Organization by the nurses illustrates their work and also describes the people with whom they worked.

\footnotetext{
"One of our obstetrical patients gave birth to triplets, two boys and a girl. In saying our obstetrical patient' I made a mistake, for the patient was not confined by one of our midwives, but by a relation, an old Urfaly woman. She (the patient) is partly ours, as we are assisting her with groceries, underwear, and, of course, visit her and watch whether anything will develop. So far, there is no indication of anything unforeseen turning up, except malaria, which is almost a general affliction in Jerusalem, few escape. The triplets are so far not worse and seem to hold their own. Two of them do not seem to promise a long life. but one cannot tell. The mother has plenty of milk for them all. When they are a little older, and I am able to persuade the parents to let me photograph them, I wil! do so and send the pictures to you. The Urfaly, the Yemenites, and some of the Persian Jews strenuously object to being photographed, thinking it will bring them ill luck ${ }^{23}$."
}

The nurses supervised local midwives, followed up the postpartum patients and neonates, cared for both the acute and the chronically ill. They referred patients to the physician for home visits, and performed other medical and nursing regimes as well as social services, such as supplying groceries and clothing for needy families provided through funds from Hadassah. In a letter of June 7,1914 , the nurses wrote that there was a great deal of sickness in Jerusalem, and that they were very busy. 
"We have not sent patients to Shaare Zedek Hospital up to now, for like a miser I kept the $\$ 500$ for use during the summer, knowing from experience from last summer what it brings in its wake ${ }^{24}$."

The patients cared for at home included all age groups suffering from many ailments. A lonely old woman with kidney disease, living in squalor, was on the nurses' case load and the nursing care consisted of hygiene, nourishment, medicine, and a physician's visit. There were always patients with malaria, typhoid fever, meningitis, and typhus in need of care 25 . In addition, the nurses started an anti-trachoma service in the schools under the supervision of Dr. Abraham Ticho, the ophthalmologist. Dr. Ticho examined the children and families and gave prescriptions for treatment; the nurses treated the patients, and later trained probationers, i.e., women from the community, to do this work, as the case load increased $^{26}$. These brief notes indicate that cooperation existed between the nurses and some physicians, there was supervision of midwives, and, above all, there was awareness of patient and community needs.

The nurses also started health clubs for schoolchildren. Language seemed to be the main difficulty. In one school, children spoke Yiddish. Spanish, Arabic and French, languages that the nurses did not speak, except for Yiddish. However, the report stated that the nurses managed to get along. Children were taught hygiene and nutrition by using the children who spoke Yiddish as translators. The Evelina de Rothschild School had English as the teaching language, and, according to one of the nurses, more health teaching could be done there, if only because she could speak in English $^{27}$

When the winter rains ended and the dry heat of the summer came, the nurses wrote: "The weather is beautiful, but it is very hot during the day and one looks forward to the evening coolness." They were very busy in the summer with malaria and intestinal disease. A typhoid case was treated at home. where the mother slept with the sick child and six other persons in the same room. It was a struggle to get the family to open the two small windows. The parents refused hospitalization for the child because an older sister had recently died of typhoid and pneumonia at Shaare Zedek Hospital $^{28}$

Summer was an especially busy time with malaria patients being treated at home under supervision of the doctor who visited from Rothschild Hospital. Some patients received injections of arsenic for anaemia; some had to be given milk and eggs because they could not afford these necessities. Almost all the patients were malnourished. Not only did the nurses concern themselves with all the needs of the patients, they also looked for bargains in supplies in order to stretch their funds ${ }^{29}$.

A typical working day for Miss Kaplan and Miss Landy consisted of giving trachoma treatment for half a day in the schools, and working in the settlement in the afternoon, where people were waiting with various requests. In addition to caring for the sick, the nurses tried to provide for the homeless orphans, the lonely elderly. and the insane. Many requests had to be refused for lack of resources.

The reports of May, June, and August 1914 give graphic descriptions of the nurses' work. The home visits multiplied in summer, probably because of an increase in gastrointestinal diseases, although this is not mentioned. It is also surprising that the reports do not specifically mention the infants and preschoolers under care. In a hot climate and under primitive conditions, infants are particularly susceptible to dysentery and dehydration, and the mortality is high. It is possible to speculate that the statistical reports requested only certain information and that the nurses saw no need to differentiate between age groups. Another reason may have been that infant welfare care on a planned and organized basis was only begun in 1906 in Cleveland ${ }^{30}$. and the two nurses in Palestine had not had the opportunity to observe preventive care for infants and preschoolers. The "treatment in schools" refers to trachoma and the high numbers for May and June reflect the heavy work load. In August the number of eye treatments had gone down; this may have been due to the summer vacations and to the lack of material for treatment. The report for August 1914 also mirrors the tense and difficult situation in Jerusalem. The total number of applicants for help had gone up from 127 in June to 334 in August; the number of "patients treated" had increased from 75 to 138 , and the figure for "persons otherwise assisted" was almost double that for May.

In their letters from the outbreak of the war in the summer of 1914 until October 1915, the nurses showed their concern regarding war developments. There were no ships arriving at Jaffa to bring money or supplies; the money question was of paramount concern to them as well as to the whole population. The banks were paying only 10 percent of any savings account; money was losing its value; prices had gone up. The health institutions were in trouble; Ezrat Nashim, the mental hospital, had discharged patients, and these people were bringing added difficulties to their families. Shaare Zedek Hospital was taking people who could pay, and accepted only very few who could not. The eye hospital. Le Maan Zion, directed by Dr. Ticho, was expected to close soon. although the eye clinic was to continue. Schools were closed since there was no money to pay the teachers. The nurses themselves were ready to continue working without salary, as they had some money in the Anglo-Palestine Bank and could subsist as long as the bank would pay out funds ${ }^{31}$.

The nurses had always helped their patients materially with funds from Hadassah, but now this stopped. Milk was obtained on credit. Lack of cotton hindered the treatment of trachoma, and the nurses looked for a substitute. Medications for treatment were given by the Le Maan Zion pharmacy until the stocks were exhausted ${ }^{32}$. Despite the hardships the two nurses continued their work until January 1915, when Miss Kaplan left Palestine for New York because of illness ${ }^{33}$. 
Miss Landy remained in Jerusalem, assisted only by two probationers in treating trachoma. She wrote that the general practitioner of the Rothschild Hospital had been expelled from Palestine because he was not an Ottoman subject, and, as a result, there was much less nursing work ${ }^{34}$. It is unlikely, however, that in a Jerusalem without the general practitioner and with fewer hospital beds, the nurse refrained from diagnosing and giving treatment and care to patients. It may be that her nurse's training as well as her modesty made her reticent about her expanded role. In addition to her routine work during the wartime period, Miss Landy taught a class in home nursing in one of the schools ${ }^{35}$

In January 1915 "quite a number" of newborns died. The nurse believed that the cause of these deaths was starvation brought on by war conditions. Even the trachoma treatment, when given, was not as successful as before; this, too, she felt, was due to lack of food. "I wish I were a better letter writer. You should see the people in the streets," she wrote to Hadassah.

\footnotetext{
"They are perfect studies of pain, misery, and starvation. I never saw such faces. You can imagine how it feels to meet people who, you can see, are hungry, yet you don't like to approach them, and they are ashamed to approach you. The Straus soup kitchen is open. What a blessing that is ${ }^{36}$."
}

There were difficulties in obtaining kerosene and soap. All this, the lack of supplies and the hunger, was hard to bear, but the new physician, Dr. Helena Kagan from Rothschild Hospital, was most helpful, and she did not take fees for all her visits ${ }^{37}$.

In June 1915 Miss Landy's contract was up, her family demanded her return, and although she wanted to stay on Hadassah recalled her ${ }^{38}$. The settlement was closed, and Miss Landy transferred the care of the patients to Dr. Ticho and Dr. Kagan ${ }^{39}$. But Miss Landy had plans for the future. She wanted more nurses, and both she and Dr. Kagan wanted a clinic for women and children in Jerusalem. Miss Landy wrote:

\footnotetext{
"I don"t know whether I had malaria or whether my fever was due to your telegram, but my temperature went up to 39 (Centigrade) and stayed there on and off until I sent you my reply."
}

She had become attached to Jerusalem and had strong feelings about leaving it at this stage: she had planned to leave it in a different way ${ }^{40}$.

The nurses" departure marked a pause in the development of public health nursing in the form of a district nursing program, since there were no prepared nurses to whom the program could be transferred. However, the success of the Misses Landy and Kaplan laid the foundation for public health nursing that was begun again in 1922 under other nurses. The first nurses had demonstrated the value of care directed to families and communities as well as individual patients ${ }^{41}$. In addition to their professional contribution, the two women through letters and reports had sketched the Jerusalem of the day for posterity.

\section{REFERENCES}

Hadassah Bulletin, 4 (August 1918), 1 - 10

Hadassah Bulletin, 2 (28 September, 1914), 1 - 3

Norman Bentwich and Helen Bentwich, Mandate Memories 1918 - 1948 (New York: Schocken Books. 1965). 24

Genesis XIII: 14.15

5 S N Eisenstadt. Israel Society (New York: Basic Books Inc., 1967), 2 - 10 The Jewish Communities that existed before the end of the nineteenth centur were known as the Old Yishuv.

7. The waves of immigration are known as Aliyot - singular Aliyah. The literal translation is "going up" or ascending (to the Holy City. Jerusalem).

8. Acronym formed from the Hebrew words for "House of Jacob, come and let us go

9. David W. Amram. "A Jewish State in Palestine", Federation of American Zionists (New York: Zionist Publications, 1918), - 18

10. V.D. Segre, Israel, A Society in Transition (London; Oxford University Press, 1971). $58-62$

11. Letter from Hadassah Medical Organization no. 2203/1380 to Zionist Organization of America. 28 March. 1921

12. S N. Eisenstadt. "The Oriental Jews in Israel". Jewish Social Studies, 12 S.N. Eisenstadt, "The
(July, 1950), $199-222$

13. Great Britain and Palestine, Information Department Papers no. 20a, The Royal Institute of International Afrairs, 1915 - 1939, (London; Oxford University Press. 1939). 4

14. S.N. Eisenstadt. "The Sociological Structure of the Jewish Community in Palestine". Jewish Social Studies, 10 (January, 1948), 3 - 18

15. Herbert Samuel. Report of the High Commissioner on the Administration of Palestine, 1920 - 1925, (Jerusalem; Govemment Office, 22 April, 1925), 6- 24 Gavemment of Palestine. Report on Palestine Administration, (London; His Majesty`s Stationery Office, 1922), 57

17. League of Nations Permanent Mandate Commission, Anexes to Minutes of the Third Session held at Geneva from 20 July. 1923 to 24 August, 1923

18. Govemment of Palestine. Report on Palestine Administration, (London; His Majesty"s Stationery Office, 1922), 64

19. Report of the Medical Board of the American Zionist Medical Unit, October, 1918

20. The Jewish Social Services in Palestine, (Jerusalem; National Council of Jewish Communily of Palestine, 1946), 34 - 38

21. Letter from Rose Kaplan to Mount Sinai Alumnae Association, 30 October. 19!3. Mount Sinai Alumnae News, January. 1914. 1 - 3

22. Arieh Tartakowr, "The Making of Jewish Statehood in Palestine," Jewish Social Studies, 10 (July, 1948), $207-222$

23. Hadassah Bulletin, no. 1, 10 September. 1914, 3; nurses' letter of 23 June, 1914

24. Hadassah Bulletin, no, 1, 10 September. 1914. 2; nurses' letter of 7 June, 1914

25. Hadassah Bulletin, no. 2, 28 September. 1914. I - 3; nurses' letter of May, 1914

26. Hadassah Bulletin, no. 4. August. 1918 ,

27. Hadassah Bulletin, no. 1, 19 September. 1914, 1 - 3 nurses' letter of 7 June, Hadas

28. Hadassah Bulletin, no. 3. 30 October. 1914. 2 - 6; nurses' letter of 19 July, 1914

29. Ibid

30. Annie M. Brainard. The Evolution of Public Health Nursing, (Philadelphia; W.B. Saunders Company, 1922), 286

31. Hadassah Bulletin, no. 4. 23 November. 1914. 2 - 7; nurses' letter of 23 August. 1914

32. Hadassah Bulletin, no, 4, 23 November, 1914,2; nurses' letter of 23 August, 1914

33. Hadassah Bulletin, no. 7. February, 1915 n.p.; in Hadassah Bulletin, no 18 February, 1916, 3, Miss Kaplan's letter of 8 December, 1915, we find Miss Kaplan in Alexandria. Egypt. caring for women and children who had been exiled by the Turks and were living in camps put up by the British.

34. Hadassah Bulletin, no. 7. February, 1915. n.p.

35. Hadassah Bulletin, no 8. March 1915, n.p.; nurses' letter of 11 January, 1915 36 Hadassah Bulletin, no. 11. June 1915, 5; nurses' letter of 24 January, 1915

37. Hadassah Bulletin, no. 11. June 1915, 5; nurses' letter of 17 February, 1915

38. Hadassah Bulletin, no. 14. October. 1915, 2

39. Hadassah Bulletin, no. 15. November $1915,2-3$

1915. Miss Landy was a graduate of the Mount Sinai Hospital Nursing School of 1915. Miss Landy was a graduate of the Mount Sinai Hospital Nursing School of
Cleveland in 1904, and became Superintendent of Nurses, Harlem Hospital Cleveland in 1904, and became Superintendent of Nurses, Harlem Hospital,
New York City, in 1911. After she left Palestine, Miss Landy entered the United States Army Nurse Corps in 1918 and served for twenty-seven years. From the obituary by Hadassah Organization, New York City, 1947

41. Letter from the American Consul, Mr. Glazebrook in Jerusalem, to Miss Léon, a Hadassah member. appearing in Hadassah Bulletin, no. 14, October, 1915.2 